\title{
4 \\ Privatizing the Public Good
}

The rapid growth of private higher education has been called part of a "multidimensional revolution" that is transforming Arab higher education systems (Romani, 2009). Private higher education in the Arab world is not new - many of the oldest and most prestigious universities in the region, including Cairo University, the American University in Cairo, the American University of Beirut, and Université Saint-Joseph, were founded as private religious colleges in the mid-1800s and early 1900s. Yet, in the post-war era, the growth of private higher education in most Arab nations was all but banned, as the government took on primary responsibility for funding and providing higher education. Since the 1980s, however, private higher education has been growing rapidly throughout the Arab world, even in countries that have long histories of predominantly public higher education systems.

By 2008 fourteen Arab nations had officially licensed private universities across the region, and since 2009 Algeria and Libya have followed suit; Algeria's first private university opened 2009. Roughly two-thirds of new universities founded in the region since 1993 are private, and a substantial number are branch campuses of Western universities (Romani, 2009, p. 4). In 2008 the number of private universities in the region stood at 150 and accounted for 41 per cent of all Arab universities (Mahmoud, 2008, p. 15), and in 2010 the percentage of students in private higher education in the Arab world stood at 17.4 (PROPHE, 2021). A decade later, Badran and Badran (2019) reported that across the region there were 300 private universities, which enrolled 30 per cent of all students, suggesting significant growth.

Private higher education is promoted by international development agencies as an efficient and effective policy solution to the challenges of rising demand and costs. At the same time, the regulation of private universities has emerged as site of major policy battles throughout the 
region, and issues such as admissions standards, composition of university boards, and accreditation have all been contested. Rather than view private higher education as a rational and efficient policy solution, this chapter examines its growth in the region and argues that it is hardly apolitical. That said, the nature of contestation varies significantly across the region. The chapter identifies an overarching pattern: the move to expand private higher education has been relatively slow and contested in North Africa and Syria, while enjoying rapid adoption and substantial growth in Jordan, Lebanon, Palestine, and the Arab Gulf states. I argue that making sense of these differences requires understanding both how state commitments to free public higher education have varied in the region and which constituencies the public system is designed to serve.

In francophone North Africa, as well as Egypt and Syria, higher education has historically operated on the principle of being universal and free. As discussed in chapter 2, access to higher education in these countries is based on ideals of universal merit, and their systems have also long promised free public higher education. Given their long traditions of framing higher education as part of the public good, even modest attempts at introducing tuition, known as cost-sharing in the development discourse, and expanding private higher education have been controversial. Students, administrators, and professors in these countries often described privatization to me as an abdication of the state's responsibility for free, high-quality public education and as a way for wealthy and well-connected elite entrepreneurs to profit from students' desires for education. Given widespread concern over privatization, their governments seek a balance between securing the approval of donors who have promoted private higher education and responding to protestations of their own citizens. In practice, they have tended to embrace private higher education rhetorically, while delaying or undermining its growth and expansion until it becomes widely accepted. Despite slow and contested implementation, however, in many countries private higher education is becoming widely accepted by many middle- and upper-middle-class families, who can afford to pay for professional education that promises better foreign-language instruction and labour market opportunities.

In contrast, other countries in the region have either implicitly or explicitly limited public subsidies to certain groups. The practice of selective subsidies is found in Jordan, Lebanon, and the UAE, countries that conceptualize students as being divided along lines of ethnicity, religion, or citizenship. In each case, public-sector funding serves particular and preferred groups, while private higher education has emerged 
and expanded to serve those who are not well served in the public sector. Private higher education has flourished but, in doing so, it undermines the state's ability to create a common national identity through its higher education system. In these cases, even when the existence or growth of private higher education is not questioned, its expansion raises educational and political debates. Seemingly technical issues regarding admissions standards or university board composition actually raise fundamental questions concerning the role of the market in providing higher education.

This chapter argues that across the region and despite the differences, private higher education is growing and raising important questions for Arab higher education systems. In formal and informal interviews that I conducted in the region, students and families viewed private higher education as part of a broader pattern of neoliberal educational policies and worried that educational credentials were increasingly "for sale," often to wealthy students (Buckner, 2013; Cantini, 2017; Farag, 2010. Students in public universities worry that their hard-earned credentials may be undermined by the proliferation of similar credentials offered in private universities. At the same time, students in private universities are concerned that they are paying significant sums of money for degrees that are not equivalent to public-sector credentials in a tiered labour market. More fundamentally, the growth of a tuition-dependent and for-profit private sector raises concerns about the state's ability to guarantee future opportunity for its young people if private higher education brings about a narrowing of curricular offerings, widening inequalities, or declining quality in the public sector.

\section{The Growth of Private Higher Education}

In the second half of the twentieth century, private higher education was practically non-existent in many parts of the world, and the Middle East and North Africa were no exception (Buckner, 2017). It was even less common in newly independent nations, which were focused on establishing higher education systems that would serve their states in both symbolic and material ways. The idea that higher education could be organized and funded by individuals or investors for profit-making purposes was either inconceivable or rejected. The important task of educating, socializing, and sorting youth into life paths was simply not left to market processes. Rather, the state, which was viewed in many parts of the world as either an arbiter of the public good or as a mediator of group interests, was considered the only legitimate provider of higher education. 
Since the late 1980s, however, privatization has spread rapidly worldwide in line with the entrenchment of neoliberalism in education and development. The academic literature on private higher education distinguishes between two phenomena: cost-sharing and private higher education. Cost-sharing refers to policies and practices that shift the burden of higher education away from the government and onto institutions, students, and families (Johnstone, 2004). It occurs within public-sector higher education and generally entails both revenue generation and cost-cutting. Revenue generation typically includes increasing tuition fees or starting new fee-paying degree tracks, such as the parallel programs discussed in chapter 2. Cost-cutting implies finding greater efficiencies, such as increasing class sizes and replacing full-time faculty with part-time lecturers. Countries around the world have had to balance increasing demand with rising costs and stagnant public funds, and cost-sharing is a global phenomenon (Johnstone \& Marcucci, 2010).

The creation of a privately owned and operated higher education sector is considered one form of cost-sharing because it allows the government to expand enrolments in higher education without expanding the public sector. However, these wholly private institutions differ in important ways from other forms of cost-sharing. Private higher education institutions are "non-state" actors - they are typically tuition dependent and operate in competitive markets for students. In many countries graduates of private universities must undergo additional regulation to have their degrees recognized by the state.

In the academic literature private higher education is thought to grow primarily to meet the needs that are not met in the public sector. The three primary reasons for the spread of private higher education worldwide are identified as "more," "better," and "different" (Levy, 2006b). By far the most common type, more means that private higher education has grown to meet demand that is not met in the public sector, due to limited capacity, inadequate resources, or geographic constraints (Kinser et al., 2010). The spread of new demandabsorbing private higher education has been prevalent throughout the Arab world; private universities are founded by a diverse range of providers, including individual proprietors, profit-seeking business interests, charitable organizations, and foundations. The private sector can also expand when it offers a "better" education. Better implies a private higher education sector characterized by high quality, endowments of substantial resources, and small classes typical of elite education. This is the model of the Ivy League institutions in the United States and universities such as the American University of Beirut and 
the American University in Cairo in the Middle East, which educate the elites of their respective countries. Although national public universities remain among the top tier of universities in many countries, the growth of the private sector has also been accompanied by the emergence of new providers, including non-profit or semi-elite private institutions, which are viewed as increasingly competing with public universities, particularly for upper-middle-class students who want more flexibility or choice over their degree (Kinser et al., 2010; Levy, 2018). Private higher education is also thought to expand when it offers something "different" from that of the public sector. This typically takes the form of a specialized curriculum, including those courses with English or other foreign languages as the medium of instruction, or offering religious education.

Private higher education is a truly global phenomenon: in the first decade of the twenty-first century, private-sector enrolments were "the fastest growing segment of higher education" (Altbach, 2005; Levy, 2006 b 2018). In 2018, roughly 32.9 per cent (about one in three) of all students in higher education worldwide were thought to be enrolled in the private sector (Levy, 2018). The Arab world is no different. Throughout the region private education is growing at all levels of schooling, from preschool to university, engendering important national debates over the legitimacy of public education, socio-economic inequalities, and the status of the Arabic language (Akkari, 2010; Benzakour, 2007; Boutieri, 2016).

\section{Apolitical Privatization}

International experts and donors have encouraged the expansion of private higher education in the Arab world, ideologically and financially. From an economic perspective, both cost-sharing in the public sector and expanding private providers seem like logical solutions. Higher education is expensive, and governments in the region already devote significant public resources to higher education. Education spending accounts for approximately 10-20 per cent of national spending; in fact, relative to their level of economic development, many Arab countries spend more on higher education than the nations of the OECD do, reflecting a strong national commitment. Development experts contend that public resources will be further burdened by the continued expansion of higher education, compelling national systems to look for alternate sources of funding. Cost-sharing is the preferred solution, and development experts conclude that "it is important that families and students contribute to its cost" (World Bank, 2011). 
From an equity perspective, access to higher education is highly unequal and tends to benefit the upper and upper-middle classes, who qualify for higher education at greater rates due in part to the better quality of primary and secondary schooling, which is often acquired in expensive or foreign-language private schools. Comparative education research from around the world shows that free higher education tends to serve as a subsidy for the upper-middle classes, who then invest in private schooling at lower levels to secure admission to higher education. Expanding the percentage of students in a tuition-dependent private sector allows governments to offset the costs of higher education and to reinvest in primary and secondary schooling. This is viewed as particularly important in low-income and lower-middle-income countries, where access to free, high-quality secondary schools is not universal. Given both efficiency and equity concerns, the consensus among many international development experts is that private higher education in the Arab world will, and should, continue to grow.

Some advocates go even further to suggest that private higher education not only is more economically efficient but may also spur improvements in quality. The dominant logic of international development experts and donors, which draws heavily on economic perspectives, argues that because private higher education has to be responsive to the market, it should be more efficient and promote high quality. In contrast, public higher education is viewed as contending with political interests and entrenched bureaucracies, which makes it less responsive to market demand. These frameworks tend to discuss private higher education as a rational and apolitical solution to the region's problems, essentially as an apolitical privatization.

Partially in response to this seeming consensus in global development, private higher education in the Arab world has grown substantially over time. At the same time, within the region the percentage of students in the private sector varies significantly. Table 4.1 shows the percentage of all students in private higher education in 2018, drawing from World Development Indicators data. The table shows that the percentage of all students in the private sector remains at or below 12 per cent in Syria, Morocco, and Tunisia. Meanwhile, the private sector accounts for the majority of all enrolments in Lebanon and the UAE, with other countries ranging between 20 and 30 per cent.

In the sections that follow, I argue that there are two overarching models of private higher education in the Middle East and North Africa: the first, in which private higher education has emerged within 
Table 4.1. Enrolment in Private Higher Education (\% Total, 2018)

\begin{tabular}{lr}
\hline Egypt & 19.9 \\
Jordan & 27.5 \\
Lebanon & 59.1 \\
Morocco & 7.3 \\
Qatar & 22.7 \\
Syria & 3.3 \\
Tunisia & 11.5 \\
United Arab Emirates & 72.8 \\
\hline
\end{tabular}

Source: WDI (2021)

Note: Includes college and university levels

states that have made official commitments to free public higher education for those eligible; and the second, in which subsidized public higher education has been selective and targeted to certain politically consequential constituencies. Moreover, I argue that, regardless of its size, private higher education remains politically sensitive throughout the Arab world. In North Africa, including Morocco, Tunisia, and Egypt, student groups have actively protested cost-sharing measures of any sort. They argue that cost-sharing in the form of tuition fees undermines legal commitments to free public education. In other countries, including Jordan, Lebanon, and Syria, new private universities have been viewed as a form of crony capitalism, with well-connected allies receiving contracts for new universities. Issues such as admissions standards and board composition have become politicized. More broadly, private higher education is contested throughout the region due to the concerns it raises over increasing inequality, declining quality, and the undermining of faith in the public sector.

\section{The Right to Free Public Higher Education}

The public university in much of the post-independence-era Arab world has traditionally been considered a nation-building institution, bringing together students from all corners of the country to forge a new identity as citizen. Differences based on tribal affiliation, religion, region, and mother tongue were downplayed as the new university graduates became the leaders and civil servants of the modern nation state. In line with these approaches, countries such as Algeria, Egypt, Morocco, Tunisia, and Syria have long-standing commitments to provide free public higher education to all secondary graduates, and in addition Algeria, Tunisia, and Syria have legacies of state socialism and 
have often promised generous subsidies. Yet, despite these commitments, in line with global trends, nations throughout the region have expanded private higher education in recent decades (Herrera, 2006; Mazawi, 2005; Reiter, 2002; Rugh, 2002).

In these countries private higher education began in the vocational sector. In the 1980s and 1990s, private, for-profit vocational colleges and institutes proliferated throughout the region, including Egypt, Morocco, and Tunisia, offering two-year certificates or diplomas. They provided advanced training or vocational skills in a variety of subjects such as management, business, and hospitality. They were distinguished from other forms of higher education in that they rarely offered opportunities for further study at university, although many have since become fullfledged universities. In an interview I conducted in 2013, the president of a private university in Casablanca explained that these institutions were "oriented towards business, and cared very little about education," stating that investors opened private universities "the way one would open a shoe store."

The expansion of private higher education, particularly in the vocational higher education sector, was actively encouraged by the WB and other development agencies. The WB gave Morocco a loan of USD 150 million in 1986 for education sector reform; in addition to explicitly promoting private schooling at the primary and secondary level, the project encouraged private-sector participation in vocational higher education. A clear goal of the reform was the "increased efforts to mobilize private financing in order to reduce budgetary costs" (World Bank, 1986, p. 11) and the "encouragement of private-sector participation" in vocational training and education (World Bank, 1991, iv).

In Tunisia private higher education as a form of vocational training began in the 1980s, also "under pressure from the World Bank," according to a former university president whom I interviewed in 2012. In 1989 the WB gave Tunisia a loan of USD 95 million, in which one of the objectives was to mobilize additional private resources for vocational training. In line with this goal, the WB championed "revising legislation for private training" to encourage private investment and the reduction of the tax on private providers of training. The project had partially met these objectives by 1997, according to the report (World Bank, 1997, Annex 2).

Since the late 1990s, however, governments have begun to permit private higher education at the university level, which is a generally more controversial move given the prestige and historic nation-building aims of the university. Scepticism over private universities has been widely recognized by Arab scholars. In 1997 Dr. A Halim (1997) wrote: 
"Public higher education should not be reduced to being a poor relative of private education, which has been encouraged with great fanfare, even though it has not even - or at least, not sufficiently - proved itself" (quoted in Emran, 1997, p. 7). ${ }^{1}$ Nonetheless, starting in the 1990s, governments across the region have committed, in official rhetoric, to expanding private universities, often building these commitments into major reform initiatives and supporting them with various forms of funding.

In Egypt a major overhaul of higher education was passed in 1992 (Law 101), a year after a large WB structural-adjustment policy had introduced privatization of other government sectors. The law permitted the establishment of new private universities for the first time since independence, although the first private universities were not licensed until 1996, when four new institutions were established (Cantini, 2017). Enrolments in private higher education began to grow: in 1999 only four private universities were operating, serving roughly 6,000 students, compared to the twelve public institutions, serving nearly 1.5 million students (Farag, 2000, p. 16). Twelve new private universities were established between 2002 and 2010, bringing the total to seventeen in 2010 (Álvarez-Galván, 2015). The number of students enrolling in private universities also increased dramatically, from 11,000 in 2000 to 48,000 in 2005, and to 70,000 in 2009 (Fahim \& Sami, 2011). The expansion of private universities in Egypt was highly contested in the media, in which access to higher education was characterized no longer as solely a matter of state planning but as operating within an open market for credentials, governed by individual calculations of costs and benefits (Cantini, 2017; Galal, 2002; Kohstall, 2012). For example, writing for the major English-language publication al-Ahram Weekly, el-Nahhas (2002) stated that private higher education was "at odds with the principles of the 1952 Revolution which calls for equal access to educational opportunities for all citizens."

Since the introduction of private higher education, twenty-four forprofit private institutions have been authorized in Egypt, most operating around Cairo and Giza and educating middle-class students in degrees that are oriented to the labour market, such as information technology, engineering, and medical sciences (Cantini, 2017, p. 136). Today approximately 20 per cent of all students in higher education are in the private sector, although the percentage in four-year, bachelor

1 “De meme il ne faut pas réduire l'enseignement supérieur public à un parent pauvre de l'enseignment privé que l'on encourage à grandes fanfare alors qu'il n'a même pas encore - ou pas suffisamment - fait ses preuves" (A. Halim, in Emran, 1997, p. 7); translation mine. 
degree-granting universities is much smaller. Two surveys of young people in Egypt, in 2009 and again in 2013, found that the percentage of university students in private higher education is less than five (Assaad, Krafft \& Salehi-Isfahani, 2018; Buckner, 2013).

In Morocco a new education law was passed in 2000 that permitted the creation of private universities. In interviews I conducted with ministry officials, one director explained that Morocco's official goal was to "keep Moroccans in Morocco," explaining that "right now, Morocco loses a lot of Moroccan students to universities abroad," and there are clear financial incentives to keeping them in the country. However, these incentives seem to conflict with a broader scepticism of private universities. In practice, no regulatory framework was adopted until 2011, which meant that investors had no clear understanding of the policies and laws governing private universities. The delay in developing the framework was widely interpreted among education officials, university presidents, and potential investors as a tactic to prevent the expansion of the private sector. The regulatory framework for private institutions was passed in 2011, and by 2014 five private universities had opened. Private universities are located in a number of the major cities in the country - Rabat, Casablanca, Marrakech, and Agadir. In 2014 there were 34,000 students in private institutions, accounting for roughly 3 per cent of all enrolments. The ministry's stated goal was to increase the number of students in the private sector to 20 per cent. However, as of 2018, only roughly 7 per cent of all students were enrolled in the private sector, and this represents a slight decline since 2014.

Only a year after Morocco's education law had been passed, Tunisia also permitted the creation of new private universities. In July 2001 Tunisia passed a law (Law 2000-73, 25 July 2000), which laid the foundation for the expansion of private higher education (MOHESRT, 2003, p. 48). The law set the minimum standards for admission, requiring that all private university students hold a secondary degree. It also set standards for faculty credentials and student-faculty ratios and allowed graduates to seek ministry equivalence - which in turn would allow graduates of private universities to continue their education or to work in the public sector. In line with this goal, the country's Tenth Development Plan (2002-6) created incentives to encourage the founding of private universities, namely grants that would cover up to 25 per cent of total founding costs and that would rebate " $25 \%$ of the salaries of full-time Tunisian teachers for a 10-year period" (MOHESRT, 2003, p. 47). Additionally, private institutions were sold parcels of land for one dinar as a symbolic gesture of support (Zghal, 2007). Tunisia's 2003 higher-education-strategy document said that these policies would ultimately support private higher education by enabling "these 
institutions to attract increasing numbers of both Tunisian and foreign students" (MOHESRT, 2003, p. 48).

Between 2002 and 2014 the number of private higher education institutions in operation grew significantly, from twelve in 2002 to forty-six in 2014 (MOHESRT, 2014). Combined, however, they attracted no more than thirteen thousand students, as private higher education institutes tend to be much smaller than public institutions, sometimes numbering only a few hundred students. The general scepticism of private higher education in Tunisia was summarized by Tunisian professor Riadh Zghal who stated that private higher education had "not managed to take off yet" (Zghal, 2007, p. 58). ${ }^{2}$ That said, since then Tunisia has seen slow but steady increases in private sector enrolments, reaching 11.5 per cent in 2018, up from 6.5 per cent in 2003 (WDI, 2021).

Around the same time, Syria also went through similar, fundamental changes in its higher education system. As part of its larger economic transition towards a market-based economy supported financially by the $\mathrm{WB}$, the republic implemented a number of educational reforms in 2001. The reforms transformed the previously free higher education system into a more differentiated system that focused on expanding access and offsetting costs. They included a new law that permitted the founding of private universities. By 2010, fifteen private for-profit higher education institutions were operating in Syria, many of which cost upwards of USD 10,000 a year to attend. It is worth noting, however, that private higher education was only a small player - in 2009, private universities enrolled 24,573 students, constituting roughly 4 per cent of all university students (Buckner \& Saba, 2010). After a decade of conflict the Syrian private sector remains very small, at 3.3 per cent in 2018 (WDI, 2021).

In all of these countries, governments officially permitted the establishment of new private universities, often in response to pressures from international development agencies; however, in practice, the expansion of private higher education was slow. My interviewees suggested that, despite a rhetoric of support from the government, private higher education was often intentionally sidelined. In 2012-13, I interviewed a number of professors, former university presidents, and ministry officials in Morocco and Tunisia, and they said that ministry officials were often openly hostile to the private sector.

In both Morocco and Tunisia, private higher education received less support than was promised officially on paper, and administrators

2 "Le secteur privé, qui bénéficie d'incitations à l'investissement particulièrement généreuses parmi lesquelles l'acquisition du terrain pour un dinar symbolique, n'a pas encore réussi à décoller"; translation mine. 
perceived their Ministry of Higher Education to be somewhat hostile. When I was conducting research in Tunisia in 2012, university administrators stated that many of the incentives for founding private universities were not honoured. The founder of one private university said that, despite promises of faculty-salary rebates, he had not received any money from the government. Another exclaimed that the Law of 2000 was supposed to "guarantee incentives, but these were never honoured." Similarly, private university administrators and ministry officials explained in interviews that while equivalence of diplomas might be legally possible, in reality graduates of private universities could not work in the public sector and would not be accepted for graduate study in public universities because this equivalence was hardly ever granted. Cantini (2017) reports that in Egypt the government failed to give private universities the autonomy they desired and closely regulated the programs they could offer.

Private higher education is contested largely because it is viewed as contradicting governmental commitments to free public higher education. In an interview in 2013 the president of a private university in Morocco explained that, for the government and the Ministry of Higher Education, expanding private higher education was "socially and politically risky" because culturally "private higher education is seen as no good." Another private-university president to whom I spoke in Morocco explained that the ministry "saw itself as the ministry of public higher education only." A strong orientation towards the French model, and its commitment to a free public system, were specifically cited as the reason for the decade-long delay in the implementation of Morocco's privatization reforms and for Tunisia's continuing hesitance to support private higher education. The president of a private institution in Tunisia told me: "Our university system is based on the French system ... and people in the ministry are products of this system. It will take some time. We need political willingness and time; people won't change overnight."

Ridha Ferchiou, the director-general of a private college, L'Institut Tunis-Dauphine, stated in 2010: "We have the impression that they [government officials] want to pit the two sectors against one another, as if they were enemies, while in other places, they are complementary to the point that there is no difference between the two" (Fatnassi, 2010). ${ }^{3}$ As

3 “On a l'impression qu'on veut opposer les deux structures, comme s'il s'agissait d'ennemis, alors que sous d'autres cieux, ils sont complémentaires, au point qu'on ne ressent aucune différence"; translation mine. 
a result, in Tunisia the strategic niche provided by private universities is in accepting the students who have failed in public universities, in serving international students, or in providing highly specialized programs. That said, the percentage of students in private higher education continues to grow as these institutions offer in-demand specializations. In 2018-19 there were twenty-eight private institutions in Tunisia offering engineering degrees, ten offering architectural degrees, and nine offering paramedical degrees (MERIC, 2019b). Additionally, there is some evidence of a competitive dynamic operating between the two sectors. For example, the first public English-language graduate school, the Tunis Business School, was founded in 2010 at the University of Tunis. The institution is considered by many to be the public sector's response to the opening of a private English-language business school, the Mediterranean School of Business, which opened in 2000 and is now considered to be one of the best business schools in Africa.

A second reason for the government scepticism of the private sector that was mentioned in my fieldwork in Tunisia and Syria is that the government is not willing to accept a private sector free from political control. For example, in Tunisia the president of one private university linked opposition to private higher education to the government's desire for political control, stating: "In 2008, Ben Ali limited PHE because he did not want it to be strong. ${ }^{4} \mathrm{He}$ did not want to lose control." He continued: "The lack of support for PHE goes back to Ben Ali. He saw higher education as a form of values education. With PHE, the state no longer has control."

Today the legal code governing private institutes remains quite restrictive in Tunisia. They are required to be for-profit commercial enterprises, cannot build regional branches, and are required to offer only one subject (akin to a school or faculty); as such, they are still officially registered as single-faculty institutions. In practice, many call themselves a university because they operate multidisciplinary institutions. Additionally, in 2008 the investment required to found a new university was raised to TND 2 million (USD 1 million), a decision made without discussion with investors (Fatnassi, 2010). Private university administrators also criticized the government's delays in approving new study programs. In interviews I conducted with the owners and administrators of private universities, they complained that new private

4 Zine el-Abidine Ben Ali was the former president of Tunisia, who served from 1987 until he was ousted in a peaceful revolution on 14 January 2011. His rule was marred by reports of extensive corruption and was considered an authoritarian regime by independent human rights groups. 
university programs are only approved if they match a similar program in the public sector, thereby depriving the private sector of opportunities for innovation, and to date, no private institution has permission to offer a doctoral degree (MERIC, 2019b).

\section{Selective Public-Sector Subsidies}

In contrast to contested private higher education policies found in North Africa and Syria, private higher education is well established in Jordan, Lebanon, and the UAE. Regardless of what a technical approach might suggest, I argue that high rates of enrolment in the private sector in these three countries do not reflect only logics of economic efficiency. Rather, their private higher education reflects their respective societal divisions. Although private higher education has grown rapidly and easily, it does so because the higher education system does not claim, or aim, to be a nation-building institution for all the people.

Jordan is considered to be a regional model for its success in expanding private higher education. In 1989 the Private Universities Act permitted private universities to operate, and the first private university was officially approved and opened a year later (Burke \& al-Waked, 1997). Most private universities in Jordan are "demand-absorbing," founded to educate the overflow of students not accepted into the public sector. However, there are also non-profit institutions founded by endowments from the royal family (e.g., Princess Sumaya University for Technology) and the Catholic diocese of Jerusalem (e.g., American University of Madaba), as well as technical colleges founded by businessmen who want to provide applied training to develop local talent in the hospitality industry (e.g., Ammon Applied University College).

Two factors jointly encouraged the growth of private higher education in Jordan: first, there was significant student demand that the public sector could not absorb; and, second, there was the desire to keep in Jordan the large number of Jordanian students who might otherwise study abroad. In the early 1990s this desire was strong. In 1987 there were 25,084 Jordanians studying abroad from a country of only 3.2 million residents - making Jordan one of the highest sending nations in the world at the time. This high number resulted both in a concern about the large investments families were making that could be used by the country's local economy, and in a desire "to avoid Jordanian students' exposure to the effects of Western culture" (Badr, 1994, p. 14), which had "negative repercussions on [Jordan's] Arab-Islamic culture" (p. 1).

In 2010, private institutions are estimated to have absorbed 35.9 per cent of all higher education students in Jordan, although this 
number has remained quite stable, ranging between 26 and 30 per cent since 2015 (PROPHE, 20201; WDI, 2021). Students in private universities pay tuition fees that are subtantially higher than the subsidized tuition rates in public universities (World Bank, 2013). For example, Badran and Badran (2019) find that average tuition fees in Jordan in public universities are USD 2,816 (including both subsidized and parallel programs), compared to an average of USD 4,525 across all private universities. Tuition fees are not regulated at private universities, although many are priced competitively with the parallel learning programs in public universities. Due to the affirmative-action policies in public universities, known as the makarim (discussed in chapter 2), private universities have grown to serve a niche Palestinian clientele. They also enrol a significant number of international students, as discussed in chapter 5 .

In Jordan, privatization is closely linked to the country's broader debates over higher education access for different groups. As discussed in chapter 2, access to higher education has long been part of a larger contract concerned with distributing the benefits of the state to a divided population. Private higher education in Jordan emerged to serve a primarily Palestinian population. The growth of private universities received a substantial boost in the wake of the first Gulf War in 1990, when 300,000 Jordanians of Palestinian origin returned to Jordan from Saudi Arabia, Kuwait, and the UAE. Many of the young returnees had no avenues to access pubic higher education in Jordan because they had not been educated in the Jordanian school system (Bataeineh, 2008; Zughoul, 2000). As a result, "they went to study in the private universities" (Reiter, 2002, p. 143). Similarly, the owners of most private universities in Jordan are of Palestinian origin, and many of the returning faculty members from the Gulf were absorbed into the private university labour market.

The Jordanian private sector initially attracted students who had not been accepted into the public system because admissions policies were politicized to benefit rural and East Bank Jordanian populations. This has led to significant growth in the private higher education sector, particularly among Palestinians. Reiter (2002) states clearly that "the emergence of private universities in Jordan, which has been a matter of public discussion in recent years, is therefore a Palestinian phenomenon, even if no one states this explicitly" (p. 157). Since this time, however, private higher education has diversified and flourished to serve a broader range of Jordanians, including the upper-middle classes who are seeking distinction or opportunities for mobility.

Private higher education is even more entrenched in Lebanon. The establishment of private missionary colleges in the late 1800 s predate 
the founding of Lebanon as a modern nation state, and today forty-five of the country's forty-six higher education institutions are private. The country's only public university, the LU, was founded in 1951, roughly a decade after Lebanon's independence. Although it remains the only public university, its many campuses collectively enrol 40 per cent of all students in higher education. As in other countries in the region, tuition is highly subsidized at the LU, and student tuition and fees are much lower than at private tuition-dependent universities, making it a first choice for many families.

As early as 1961 a framework for founding new private higher education institutes existed in Lebanon (Private Higher Education Act of 26 December 1961). However, the country's devastating civil war which lasted between 1975 and 1990 caused major disruptions to the higher education system, damaging facilities and resulting in significant emigration. After the Lebanese civil war ended, two laws were passed in 1996 to regulate further the creation of new private higher education institutions, and dozens of private universities were founded in its wake. Today, there are roughly fifty private higher institutions in total and they enrol about 60 per cent of all students in higher education.

Most of Lebanon's higher education institutions are affiliated with a religious sect or divided between predominantly Christian or Muslim campuses. During the civil war, sectarian divisions became entrenched; the Lebanese American University established a second Byblos campus to accommodate Christian students and others from the north who were not able to reach the Beirut campus. Over time, the Byblos campus remained predominantly Christian due to its location and history, while the Beirut campus was predominantly Muslim (B.S. Anderson, 2011). Yet, the extent of privatization in the higher education system perpetuates identification with sect and stereotypes, undermining the role of the university in promoting nation-building (B.S. Anderson, 2011).

Moreover, the privatized system is supported by public funds: roughly 75 per cent of government employees receive tuition vouchers for private universities (Waterbury, 2020). The fact that government spending helps its public sector employees enrol in private universities seems to reflect the country's deep sectarianism and a lack of faith in the Lebanese state institutions more broadly.

The Arab Gulf states also tend to have robust private higher education sectors, and expanding private higher education has been an explicit policy goal of these governments (Levy, 2011). Private higher education has grown rapidly in countries throughout the Arab Gulf states, including not only the UAE and Qatar but also Bahrain, Oman, and Kuwait. It is worth noting, however, that most of these private institutions do not 
compete directly with public institutions for students; they are simply serving different groups of students. This is because, throughout the GCC, higher education has historically been conceptualized as having two distinct sectors, with the public sector catering to citizens and the private sector largely serving non-citizens (Romani, 2009).

In Qatar, citizens make up almost two-thirds of all students in the country's higher education system, and they are disproportionately enrolled in the public system. Official statistics from 2017-18 show that Qataris made up 71 per cent of all students in the public colleges and universities, while comprising only 52 per cent of students in Education City universities and 44 per cent of those in other private colleges and universities (PSA, 2018).

Similarly, in the UAE, the free public, federal universities and Higher Colleges of Technology (HCTs) cater to Emirati citizens, while private higher education has emerged to educate non-citizens, who constitute the majority of residents (Romani, 2009). Data available from the UAE Ministry of Education shows that in the 2018-19 academic year, 93 per cent of all students enrolled in the public federal universities were Emiratis, while only 44 per cent of students in non-federal institutions, which are largely private, were Emirati (MOE, 2020).

The growing and diverse private sector caters to a large non-national student body, which includes both resident non-citizens and an increasing number of foreign student-visa holders. Encouraging the growth of private higher education is part of the country's commitment to developing what it characterizes as homegrown and highly skilled talent for the labour force, which the UAE hopes will reduce its dependence on costly recruitment of those educated abroad. In 2012, the minister of higher education and scientific research stated that both the public and the private sector will "play an essential role" as the UAE transitions to a knowledge economy (Sherif, 2012).

Interestingly, a significant number of Emiratis are also now enrolling in the private sector, complicating the traditional sectoral division. In 2017, statistics show that Emirati nationals made up more than 22,000 of the roughly 60,000 students enrolled in Dubai's branch campuses (KHDA, 2017), representing more than a third of all students and suggesting a growing demand for private higher education among Emirati citizens. Seemingly in response to this growth, the regulation of private higher education has recently become a policy priority. Stricter regulation of the private sector seeks to ensure that students and families trust the higher education system and also supports the government's goals of training a highly skilled labour force locally. Accordingly, a number of emirates have been tightening regulations on private higher education 
in the name of quality assurance. For example, in 2017, Ras al-Khaimah announced that it would be introducing stricter policies for private universities, and some institutions have been forced to close as a result.

\section{“Selling Degrees"}

The overriding perception in the region is that, in contrast to public higher education, which is a public good supported by the state, private higher education is a business. Excess demand for higher education has meant that private higher education is seen as a sound investment for local investors, and in interviews I have conducted in the region, investors gladly admit that they view higher education as a strategic business opportunity. Amal Abou-Setta, an Egyptian academic who previously taught at private Egyptian universities, summarizes some of the critiques in his statements to the media: "I taught in six private universities in Egypt, and I can confirm that ... they are for the most part investment projects that aim for profit at the end of the day, regardless of the quality of the service" (Abou-Setta, 2014). In interviews I held with professors and higher education administrators in Jordan, Morocco, Syria, and Tunisia, most criticized private universities as "selling degrees," with one interviewee calling them "commercial enterprises, not educational institutions." For example, one administrator at a private university in Morocco explained that "there are forty or so private institutes, but only four or five of them are worth considering a university. The rest are just trying to make money."

In some countries, such as Tunisia, private universities are actually required to be for-profit because no legal code exists for a private nonprofit university. In other countries, such as Jordan, universities are legally required to be non-profit, but investors can exploit loopholes that allow them to make substantial profits. For example, investors create shell companies that let the land and buildings to the university at high rates. This practice is carried out in plain sight, and government officials are sometimes shareholders.

In addition, in many countries in the region, private university boards and investors are granted significant power or have political connections that exempt them from burdensome regulations. In Lebanon it is widely acknowledged that new private universities are linked to dominant political parties and political elites, who act as patrons and buffer them from regulation that might cut into their profits. The lack of a buffer between private universities and political leaders means that regulating private universities often has a direct impact on the wallets of politicians, making them less interested in closely regulating quality. 
Similarly, in Jordan, private entrepreneurs often have a large say in issues of university governance. In a comparative study of university governance in the region, the WB found that investors have large decision-making roles in private universities, while faculty, administration, and students all have much less decision-making power in private universities than they do in public institutions (World Bank, 2013).

In Jordan, debates over how to regulate the private sector have had to negotiate with powerful investors. The local media has publicized the fact that many founders of private universities, who typically serve as university board presidents, do not have a university degree, which has undermined public faith in their quality and led to numerous policy battles over the composition of university boards. In 2001, laws were passed to ensure that private universities maintained minimum levels of academic quality. One law required that all board members hold a bachelor's degree and stated that no investor could serve as the president of a university. Investors vocally protested these new requirements, stating that the government was interfering in their investment properties (al-Farawati, 2001). In 2002 the minister of higher education initiated a dialogue with private universities to discuss the issue of high fees, stating to the press: "We want them to make profit, but we do not want the education process to become merely a profit-making enterprise" (al-Farawati, 2002).

These debates over standards in the private sector have played out over two decades without much resolution. External pressures may induce change, however: in 2019 both Qatar and Kuwait, countries that send a combined 5,000-7,000 students to Jordan for higher education as fee-paying international students, decided to cut dramatically the number of institutions whose degrees they would recognize. Of the twenty-nine universities currently in Jordan, Kuwait will now accredit only five, down from twenty, and Qatar will recognize six, all of which are public except for the Princess Sumaya University for Technology, the country's only private non-profit university. The majority of affected institutions were private, where, Othman (2019) argues, dubious practices have reigned for years. Othman (2019) reports that some universities have lower standards for international students, who pay higher fees, while others allow students to enrol in off-campus master's degrees and graduate in a matter of months.

As public systems are heavily subsidized and have well-established reputations, they remain the first choices in most Arab countries. In contrast, admissions to private higher education institutions are based on market mechanisms - essentially lowering admissions standards when their market position is precarious and raising them when 
demand outstrips supply. In practice, most private universities have lower admissions standards than public universities do. In Jordan, Tunisia, Egypt, and Syria private universities are all permitted to accept students who have either failed to gain acceptance to public universities or failed out of public universities. As a result, private universities are often considered "an education of last resort" (Ouelhezi, 2009).

Technical debates over admissions standards often become politicized, as governments seek more control over quality and owners eschew regulation that would decrease demand and thereby cut into profits. For example, in 2002 the Egyptian Ministry of Education established a minimum score of 80 per cent on the thanaweya amma for students specializing in science at private universities, and a minimum of 65 per cent for those in literature and the humanities ("Crunching the numbers," 2001). These benchmarks are far below admissions requirements in the public sector, where medicine requires scores above 95 per cent and engineering programs typically require 88-92 per cent (Mahmoud, 2008; el-Sebai, 2006).

Similarly, in Jordan, admissions standards are raised or lowered in response to criticisms. In 2003, minimum admissions standards to private universities were lowered to 50 per cent on the national secondary-school exit exam (Carroll, 2003). Then in 2010, in response to concerns about quality, they were raised to 60 per cent but remain lower than the 65 per cent required for acceptance to public universities (Malkawi, 2013). These changing policies reflect the difficulty governments face in balancing investors' desires to make money and popular perceptions of the low quality of private universities.

The growth of a demand-absorbing private sector has contributed to deepening concerns over the quality of higher education. Dr. Adnan El Amine, director of the Lebanese Association for Educational Studies, was pessimistic about the relationship between quality and privatization. He exclaimed that in the wake of permitting new private universities "we have now two types of failures: one is that in private universities there are no real standards regarding the quality of work, and they are working just for getting money .... and, at the same time, the crowded public university is still crowded."

Based on ethnographic fieldwork at October 6 University, a for-profit private university located in a developing district on the outskirts of Cairo, Cantini (2017) writes that many private universities "deal openly with students as customers" despite also needing to establish their reputations and prove their quality to sceptics (p. 262). He argues that private higher education is increasingly viewed as a commodity, with universities "providing services" and students being increasingly 
treated as "customers" (p. 262). He says that private universities, in contrast to free public universities, which are viewed as "a right," are changing how they interact with students, often emphasizing notions of "care" to attract fee-paying students. If the logic of the public sector is one of rights, the logic of the private sector is one of value, where those who can afford better care or better credentials are able to acquire them. Barsoum (2017) has called this the "allure of easy," whereby in Egypt students who pay substantial fees for their education expect to obtain a degree. In interviews she conducted with graduates of public and private institutions in Cairo, she found that both students and professors understood the unwritten guarantee of "passing." One student, a graduate of a public university, joked that at the private universities "you have to bribe them to fail you" (p. 111). In my own interviews in Tunisia, a professor at a public university echoed this sentiment, exclaiming that the private universities are voleurs (thieves) and are full of sub-Saharan Africans "because they guarantee a degree." These well-documented concerns over quality are particularly worrying when they facilitate the entry of wealthy but underqualified young people into high-prestige professions that involve public safety, such as medicine and engineering.

\section{Exacerbating Inequalities}

Private higher education is viewed as increasing the importance and role of family wealth in helping young people obtain advantages under the new higher education reforms. Although competitive programs in the public sector remain the most prestigious options in most countries, there are also legitimate concerns that a rapidly growing private sector will magnify inequalities in access and erode the quality of public higher education. Indeed, research in the sociology of education has found that expansion of higher education exacerbates wealth inequalities when the upper classes are able to use their financial and cultural capital to disproportionately gain access to additional spots in higher education.

The fact that private universities are tuition dependent and often charge significant fees raises concerns that a family's financial resources will determine access. Individuals from wealthy backgrounds are able to pay expensive tuitions at private universities to study a desired subject when they have been denied access to the equivalent program at a public university. The wealthy can also pay for private tutors in difficult subjects in university and so are more likely to be accepted into graduate programs. 
For example, Syria's reforms, which expanded options for studying in the private sector, were viewed by many young people as exacerbating the role of wealth in determining access to university. In interviews I conducted in Syria in 2009, when private higher education was just emerging, many young people expressed that the role of family wealth in determining access to university was "unfair." One young man, who worked full-time in a small clothing factory to support his family, explained the difficulty faced by those from his background in pursuing advanced degrees: "You need a master's or a doctorate to make money, but you need money to get a master's or doctorate." Another young woman shared his sentiment, stating that "money makes educated people, not the other way around."

The reforms were particularly criticized for helping wealthy youth access high-paying, high-prestige career paths (e.g., medicine and dentistry). For example, although admission to a medical school at the public university requires extremely high marks on the secondary-school exit exam, the new reforms allow academically weaker students to acquire the high status of a medical degree by paying to attend a private medical school. Those in the public system resent this alternative pathway to elite status. Ahmed, a very high-achieving young man enrolled as a medical student at a public university, complained about the flood of new doctors into the profession and the reduced status that his degree now brings. He stated: "The biggest problem in Syria from the perspective of human medicine is the private universities. Private universities require lower grades and still graduate doctors. Medicine takes skills, intelligence, abilities that aren't found in all students. Some students have a little, or a lot, of money and at a private university that makes them a doctor." His concern was not simply about the labour market competition but also about the social status of doctors. Social status used to be doled out by performance on academic exams alone, but for many young people it appears to be for sale to those whose academic achievement is not as high. As an individual who benefited from the former organization of status allocation, this young man resented the new system, which allowed students from particular backgrounds to alter the rules of play.

Egyptians have also been highly critical of private universities; scholars have contended that "a two-tier system is effectively set up under which the wealthy have access to a higher quality education" (el-Nahhas, 2002) or that "less affluent students will not be able to enroll in these institutions, placing them at a disadvantage to the rich" (Fahim \& Sami, 2011, p. 60). Gambetta and Hertog (2017) summarize deep criticisms in Egypt that claim that the elites have fled the public 
system: "The crony capitalists sent their children to expensive private universities such as the American University in Cairo, while public universities were resource starved and left to rot" (p. 37).

In 2012, I examined patterns of access to higher education in Egypt and found that recent higher education policies were contributing to an expansion of the higher education system, allowing a greater proportion of students to attend university. I also found that academic achievement - and the ability of the upper classes to ensure that their children enrolled in the academic secondary school track and achieved higher scores on the exit exam - seemed to be the major source of perpetuating inequalities in access to the public sector. In contrast, privatization was associated with an exacerbation of family wealth and geographical location in determining access. The private sector has grown to serve a niche clientele - wealthy families whose children do not score high enough to enrol in their desired major in the public sector, and particularly those concentrated in Cairo. The ability of wealthy families to enrol in academic secondary schools and then achieve higher scores on the thanaweya maintains their advantage in the public sector. This suggests that family wealth plays a large role in students' early lives by ensuring academic success at lower levels of schooling, which allows them to gain admission to the public sector. In contrast, the relationship between family wealth and enrolment in the private sector is the direct result of the ability to pay tuition fees and access campuses. These realities do not go unnoticed or uncontested. In Jordan the student movement Thab7toona, which translates into "You have slaughtered us" - a reference to students' discontent over policies that leave them hopeless - has expressed concern that the university may become something that only the wealthy can afford (Cantini, 2012).

Although access to public universities is unequal and biased in favour of urban and wealthy youth, an underlying logic of meritocracy still exists, and females, rural students, and the middle classes are increasingly gaining access to public higher education. In contrast, private universities are governed by the logic of family resources and individual preferences, which has tended to exacerbate inequalities in access.

\section{The Private Sector and the Public Good?}

In addition to its impact on inequality, the growth of the private sector raises a number of concerns for both the public sector and the state's ability to support social and economic development. One of these concerns involves curricular offerings: due to market competition the academic offerings of private universities tend to be narrower 
and more technical than those of public universities, focusing on those programs that are perceived as in demand in the labour market (Levy, 1999). Private universities also tend to limit investments in physical infrastructure, including in programs that require specialized or costly equipment or laboratories. In the long run, this may lead to underinvestment or fewer graduates in both the basic sciences and the arts and humanities. Simultaneously, large increases in the number of graduates with applied specializations have raised concerns over how to absorb them into the local labour market.

A second major concern is the possible erosion of public-sector quality. There are reasons to be concerned about private higher education leading to an under-investment in public education. For example, due in part to its expansive private sector, the Lebanese government spends much less on tertiary education per capita than other countries in the region do. Table 1.1 shows that public spending per student in Lebanon is only 19.5 per cent of GDP per capita compared to 25.3 per cent in Jordan, 54.7 per cent in Tunisia, and 82.1 per cent in Morocco. More privatized systems may also result in greater inequalities in access if families are left to fund tuitions on their own.

At the institutional level, private universities can also undermine the quality at public institutions by hiring professors away at higher wages or by skimming the best students. It is common for professors at public universities to combine class sections or skip lectures in order to moonlight at private universities or private language centres, a practice many of them view as justified by their low wages (L. Anderson, 2012). One of the concerns is that students at public universities may be losing the opportunity to build relationships and learn from their country's best and brightest professors.

In fact, it is not impossible that private universities will emerge as a more desirable option than public universities, even in countries where the opposite is true today. If private higher education institutions target the socio-economically elite through appeals to quality or status, they may eventually draw students away from public institutions. This "elite flight" may be particularly likely if privatization is accompanied by under-investment in the public sector. Farag (2010) has warned that this is already occurring in Egypt, where privatization has meant that public universities now "suffer from rapid devaluation" (p. 289). If private higher education institutions continue to charge high tuition to attract the best faculty and provide high-quality resources, it is possible that they could exacerbate inequalities not only in access but also in the quality of education received by students from different backgrounds. 
This chapter argues that, despite being a preferred policy solution in the development literature, privatization is hardly apolitical. In many parts of the region, particularly those with long-standing commitments to free public higher education, any form of cost-sharing or privatization is interpreted as threatening state commitments to the provision of free higher education. Yet, despite their detractors, it is also clear that private universities are growing, in part because they meet the demands of students who are not well served in the public sector. Some allow students to study a topic that they could not have studied in a public university, or to study in an English-language environment; others offer students the opportunity to simply study, after having been denied entry to the public system. One of the most important questions moving forward will be how Arab governments regulate the private sector, including issues of quality, profit-making, and scholarships, none of which are apolitical matters. 